DEPÓSITO LEGAL ZU2020000153

Esta publicación científica en formato digital

es continuidad de la revista impresa

ISSN 0041-8811

E-ISSN 2665-0428

Revista

de la

Universidad

del Tunlia

Fundada en 1947

por el Dr. Jesús Emrique Lossada

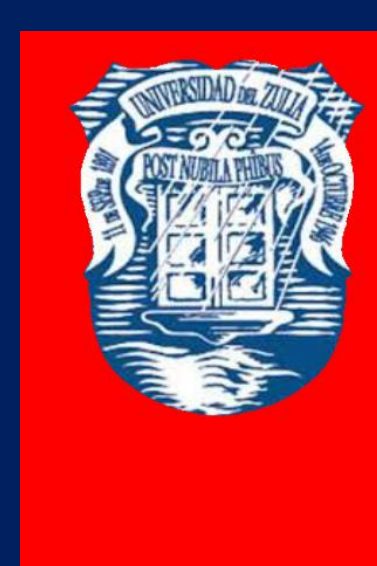

Ciencias

Sociales

y Arte

Aกัต 11 No 31

Septiembre - Diciembre 2021

Tercera ípoca

Maracailbo-Venezuela 


\title{
The development of professional self-organization among students
}

\author{
Inna K. Kirillova * \\ Evgeniia N. Khusainova** \\ Elzara I. Koikova *** \\ Irina V. Khlyzova \\ Ekaterina I. Artamonova *****
}

\begin{abstract}
The growing volumes of information and rapidly changing requirements of the professional training of students in higher education institutions make it necessary for students to seek internal reserves to master professional skills. In modern conditions, the process of professional self-organization of students is being updated. This is reflected in the requirements of the new Russian federal state educational standards of higher education in the form of key general competencies. One of them is "the ability to manage your time, build and implement the path of self-development based on the principles of education throughout life." The purpose of the article is to review the experience of developing professional selforganization among students. Professional self-organization can be understood as the process of mobilizing the capacities of the individual to achieve goals. Professional selforganization is a constantly evolving process of internal rationalization of educational activities. The crucial thing in the learning process must belong to the control of the student, since the learning activity is characterized by the active position of the student. The article presents the experience of developing the self-organization competence based on the example of the study of the cycle of general humanistic disciplines. Both individual and group forms of work are used in the training of students, electronic means are involved. To develop independence, students, with the advisory support of a teacher, complete projects, cases, tests, final assignments and other tasks. The training of the competence under consideration allows the future specialist to successfully analyze the task, contributes to rational planning, proper evaluation, timely adjustment and improvement of the process of educational activity and its management.
\end{abstract}

KEY WORDS: competence, independent study, professional self-organization, professional training, self-realization.

* Moscow State University of Civil Engineering, Moscow, Russia, ORCID: https://orcid.org/00000002-9873-4832

* North-Caucasus Federal University, Stavropol, Russia, ORCID: https://orcid.org/0000-00022915-9977

*** V.I. Vernadsky Crimean Federal University, Prospekt Vernadskogo 4, Simferopol, Russia, ORCID : https://orcid.org/0000-0001-5404-121X

**** State Educational Institution of Higher Education of the Moscow Region of the Moscow Region State University, Russia, ORCID : https://orcid.org/0000-0001-9403-9333

***** State Educational Institution of Higher Education of the Moscow Region of the Moscow Region State University, Russia, ORCID : https://orcid.org/0000-0002-9181-8005

Recibido: 01/07/2020

Aceptado: 08/09/2020 


\section{El desarrollo de la autoorganización profesional entre los estudiantes}

RESUMEN

Los crecientes volúmenes de información y los requisitos rápidamente cambiantes de la formación profesional de los estudiantes de las instituciones de educación superior hacen necesario que los estudiantes busquen reservas internas para dominar las competencias profesionales. En las condiciones modernas, el proceso de autoorganización profesional de los estudiantes se está actualizando. Esto se refleja en los requisitos de los nuevos estándares educativos estatales federales rusos de educación superior en forma de competencias generales claves. Una de ellas es "la capacidad de administrar tu tiempo, construir e implementar el camino del autodesarrollo basado en los principios de la educación a lo largo de la vida". El propósito del artículo es revisar la experiencia de desarrollar la autoorganización profesional entre los estudiantes. La autoorganización profesional puede entenderse como el proceso de movilizar las capacidades del individuo para lograr metas. La autoorganización profesional es un proceso en constante evolución de racionalización interna de las actividades educativas. Lo crucial en el proceso de aprendizaje debe pertenecer al control del alumno, ya que la actividad de aprendizaje se caracteriza por la posición activa del alumno. El artículo presenta la experiencia de desarrollar la competencia de autoorganización a partir del ejemplo del estudio del ciclo de disciplinas humanísticas generales. En la formación de los estudiantes se utilizan formas de trabajo tanto individuales como grupales, se involucran medios electrónicos. Para desarrollar la independencia, los estudiantes, con el apoyo asesor de un docente, realizan proyectos, casos, pruebas, trabajos finales y otras tareas. La formación de la competencia en consideración permite al futuro especialista analizar con éxito la tarea, contribuye a la planificación racional, la evaluación adecuada, el ajuste oportuno y la mejora del proceso de la actividad educativa y su gestión.

PALABRAS CLAVE: competencia, estudio independiente, autoorganización profesional, formación profesional, autorrealización.

\section{Introduction}

The period of development of post-industrial society is characterized by increasing information flows, the emergence of new methods and means of information processing, innovative technologies, and digital tools. There are new requirements for training a highly qualified competent specialist (Klinkov, 2018). Today, the student must quickly navigate in rapidly changing conditions (Pisarenko, 2019). Therefore, there is a need to find ways of professional self-organization of students to independently organize their activities and get high results in a short time.

Self-organization is characterized by the initiative of the individual (Andriushchenko, 2018), compliance with personal and professional goals (Aleksieienko-Lemovska, 2019; 
REVISTA DE LA UNIVERSIDAD DEL ZULIA. $3^{\text {a }}$ época. Año 11 N 31, 2020 Inna K. Kirillova et al. /// The development of professional self-organization among students, 497-508

DOI: http://dx.doi.org/10.46925//rdluz.31.32

Andrienko, 2019a; Andrienko, 2019b). Professional self-organization can also be understood as the process of mobilizing individual capabilities to achieve educational goals (Donetskova, 2019). Professional self-organization is important for a bachelor's professional activity (Oros, 2018). Its competitiveness depends on the ability to quickly make independent decisions in non-standard situations, the ability to analyze their actions, quickly identify the causes of failures and adjust their activities under them (Chertovskikh, 2019). The essence of professional self-organization is to create a new organization of the learning process at the University (Raven, 2017). The most important feature of self-organization is its purposeful nature (Cirdan, 2019), which allows the student to accumulate and use previous experience for performance and self-assessment (Tsarapkina et al., 2019). Professional self-organization performs educational (Grigoriev et al., 2019), developmental, managerial functions, and the function of ordering actions (Raven et al., 2017). The article presents a study that is carried out in the form of checking the formation of the competence "the ability to manage your time, build and implement a trajectory of self-development based on the principles of education throughout life" and by surveying students' self-esteem. Verification of competence formation is carried based on checking the summary statements for the disciplines of complex modules: "Educational and professional associations in the educational space", "Fundamentals of management culture", "Strategies for personal and professional development". In the course of training, students perform various types of tasks aimed at forming self-organization. Students evaluate their progress in studying the disciplines of complex modules.

\section{Theoretical framework}

Researchers highlight many definitions of the concepts of "self-organization" and "professional self-organization" (Bakharev, 2019). N.S. Kopein believes that self-organization is a conscious set of motivational-personal properties that are embodied in certain results of the activity.

Self-organization can also be considered an independent, systematic, ordered educational activity of students (Petrichev et al., 2018). A.V. Kirilova claims that professional self-organization is an ordered personality structure, which manifests itself in the construction of competency-building activities. 
REVISTA DE LA UNIVERSIDAD DEL ZULIA. $3^{\text {a }}$ época. Año 11 N 31, 2020 Inna K. Kirillova et al. /// The development of professional self-organization among students, 497-508

DOI: http://dx.doi.org/10.46925//rdluz.31.32

An increase in the number of publications on the issue of professional selforganization and self-control in the field of education indicates a growing interest of researchers in this topic.

The most common issues of self-organization are reflected in the works of A.A. Andreeva, S.I. Arkhangelsk, Yu.K. Babansky, P.Ya. Halperin and others. Features of the implementation of self-control by students of higher educational institutions are considered by I.L. Naumchenko. The ratio of control and self-control is presented in the works of O.V. Komova (Komova, 2015).

An analysis of pedagogical and methodological research suggests that selforganization occupies a significant place in the vocational education system and in its management structure. The transfer of a significant part of the work with educational materials to students imposes new requirements on the teaching methodology and on the development of its diagnostic tools, according to A.V. Bykov, N.S. Kopein, A.D. Ishkov and some other researchers. O.V. Komova supports the position of the above authors (Komova, 2015).

The formation of self-organization competencies allows students to be more active in the learning process, to carry out better training for training sessions - I.Yu. Lutseva (Lutseva, 2014).

Among the most significant components of professional self-organization, it is worth highlighting goal setting, forecasting (Filchenkova, 2019), planning, self-monitoring, reflection, and adjustment of activities (Halatsyn et al., 2019). These components are most often considered in interaction with the personal qualities of the subjects, which give an impetus to the development of the self-organization process (Pliushch, 2018).

The role of self-organization in competency building is considered by $Z$. A. Tolkanuk (Tolkanuk, 2019). YES. Pisarenko considers independent activity as an important tool for the formation of students' professional competence (Pisarenko, 2019).

Self-organization is an object of management both on the part of the student and on the part of the teacher (Vaskovskaya, 2018). The teacher acts as a consultant who directs the activities of students (Pichugina et al., 2019). The teacher controls that the interaction of students is in the nature of cooperation, motivates them to develop self-organization by independently completing tasks, creating success situations, introducing innovative 
REVISTA DE LA UNIVERSIDAD DEL ZULIA. $3^{\text {a }}$ época. Año 11 N 31, 2020 Inna K. Kirillova et al. /// The development of professional self-organization among students, 497-508

DOI: http://dx.doi.org/10.46925//rdluz.31.32

technologies, electronic educational tools (Ponachugin et al., 2019). The principles underlying self-organization contribute to the creation of focused development of students' desire for self-education (Vaganova et al., 2019b). An analysis of the scientific literature allows us to talk about the high importance of self-organization for a student (Gladkov et al., 2019). The higher the level of self-organization of students, the more opportunities for selfrealization and creative expression in activities (Vaganova et al., 2019a).

\section{Methodology}

The study, conducted in 2018, 2019, was attended by students of pedagogical areas of training in the amount of 38 people. The study was conducted in disciplines, the implementation of which is carried out in the second year of study.

The study checked the level of competency formation, reflecting the ability of students to self-organize "the ability to manage their time, build and implement a self-development trajectory based on the principles of lifelong education" in the process of studying the disciplines of complex modules. Competence includes three components: motivational, cognitive, and activity. Their verification was carried out with the help of complex works, which include testing, projects, term papers, case studies and other tasks.

As part of the study, motivation was checked using the method of T.I. Ilyina. Measurement of motivation was carried out on three scales: the desire to acquire new information; the desire to acquire professional knowledge and the formation of professional competencies; desire for the search and independent use of new tools and methods for studying materials. The cognitive component is formed by students performing independent work. The formation of the component depends on the quality of the work performed (projects, cases and others). Verification of the formation of the activity component is carried out by analyzing the activities of students in the framework of term papers, conducting discussions, preparing for games and other activities.

In order to verify the formation of competence in self-organization, respondents were asked to express their agreement or disagreement with a number of statements regarding self-organization and the rationality of using one's own time.

To conduct the study, the students were offered the following statements: "I systematically perform tasks without delaying the resolution of important issues"; "I 
REVISTA DE LA UNIVERSIDAD DEL ZULIA. $3^{a}$ época. Año $11 \mathrm{~N}^{\circ}$ 31, 2020 Inna K. Kirillova et al. /// The development of professional self-organization among students, 497-508

DOI: http://dx.doi.org/10.46925//rdluz.31.32

characterize myself as a purposeful person and always achieve my goal"; "I persist in achieving the goals"; "I responsibly approach to the implementation of tasks and hand them over on time"; "In self-organization, I use external means that allow me to better do my own work." The presented statements allow the opportunity to form an idea of students' selforganization according to separate indicators: "determination", "systematicity", "perseverance", "responsibility", "self-organization using external means".

\section{Results and discussion}

According to the Federal State Educational Standards of the new generation, students need to have the ability to self-organize. Following the curriculum, the formation of the competence "the ability to manage one's time, build and implement a self-development trajectory based on the principles of lifelong education" is carried out in classes on the disciplines of complex modules: "Training and professional associations in the educational space", "Fundamentals of managerial culture" , "Strategies for personal and professional development."

Indicators of achievement of competency are:

- the student's ability to determine their resources and opportunities and limitations to achieve their goals;

- the student's ability to independently build an individual educational trajectory;

- possession of the ability to rationally distribute time and information resources;

- the ability to generalize and transmit their achievements in solving the problems of self-development.

Three components can be distinguished in the structure of competence: motivational, cognitive, and activity.

The motivational component reflects the students' desire for self-realization through self-organization and independent task execution. The cognitive component is characterized by the quality of independent work. The activity component allows you to determine whether students can organize their activities.

The study of the above disciplines is carried out both in the process of group and individual work. Students perform work on term papers, projects, case studies, essays, tests. Students exercise self-control and reflect on activities. To do this, they use electronic tools 
REVISTA DE LA UNIVERSIDAD DEL ZULIA. $3^{a}$ época. Año $11 \mathrm{~N}^{\circ}$ 31, 2020 Inna K. Kirillova et al. /// The development of professional self-organization among students, 497-508

DOI: http://dx.doi.org/10.46925//rdluz.31.32

located on the educational platform Moodle. They watch video lectures, listen to audio materials, participate in webinars, use the capabilities of chat rooms and forums to discuss topics. On their own, with the advice of a teacher, they adjust their work. According to the results of comparing the data of the consolidated statements, the level of competency formation at the beginning and end of the study was revealed.

The level of competency formation is presented in Figure 1.

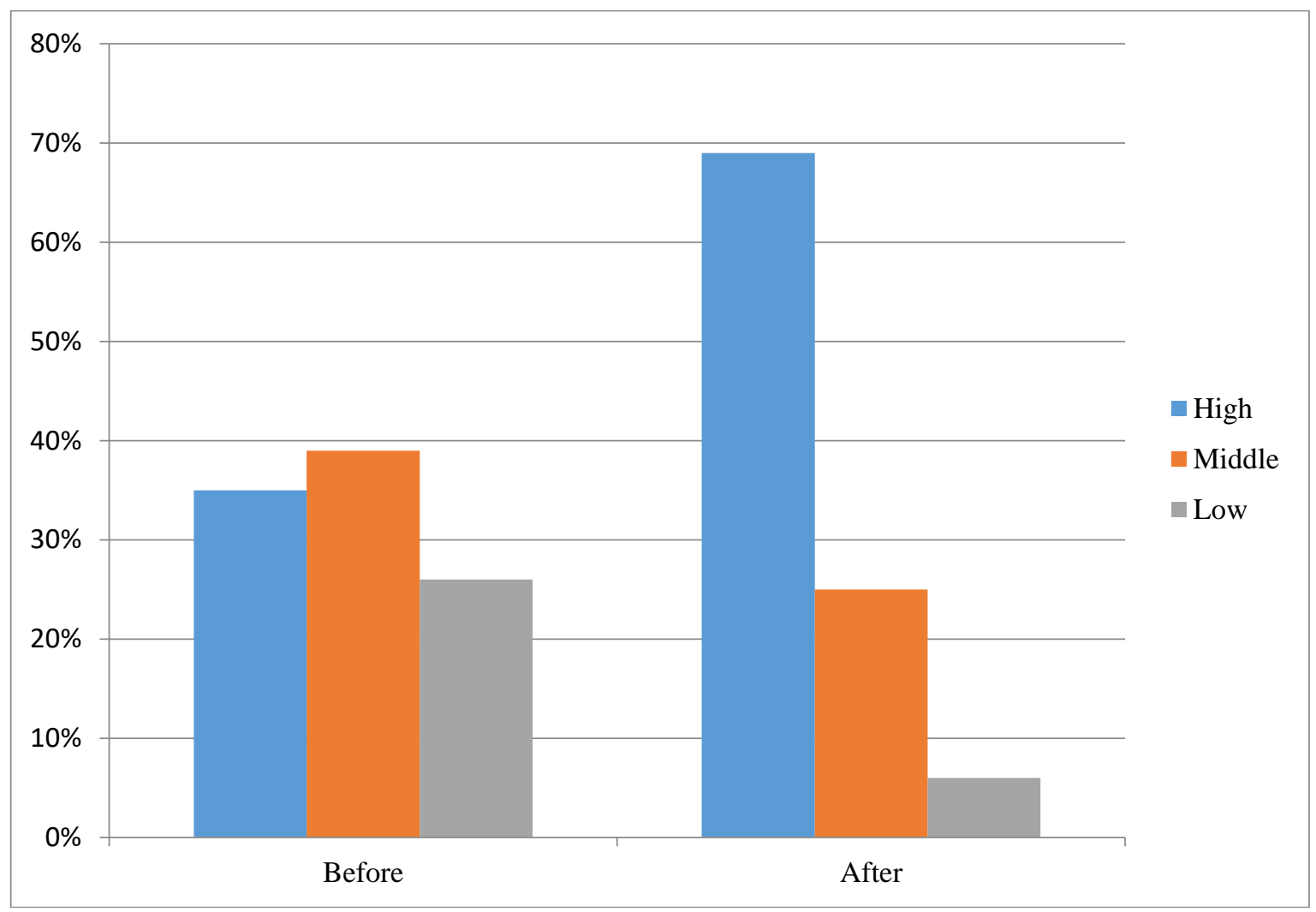

Fig. 1. Diagnostic results of the level of competence formation of self-organization (as part of our study)

The data in the figure reflect the positive dynamics of the level of competence formation "the ability to manage one's time, build and realize the path of self-development based on the principles of education throughout life".

There is a tendency for students to continuously move to a higher level of selforganization.

During the study, students were allowed to self-evaluate their activities using statements about self-organization, which they needed to confirm or refute. Table 1 presents the results of the survey before and after the study. 
REVISTA DE LA UNIVERSIDAD DEL ZULIA. $3^{a}$ época. Año $11 \mathrm{~N}^{\circ}$ 31, 2020 Inna K. Kirillova et al. /// The development of professional self-organization among students, 497-508

DOI: http://dx.doi.org/10.46925//rdluz.31.32

Table l. The results of students' survey to evaluate their self-organization

\begin{tabular}{|c|c|c|}
\hline \multirow[t]{2}{*}{ Statement } & \multicolumn{2}{|c|}{ Answers } \\
\hline & $\begin{array}{l}\text { At the beginning of } \\
\text { the research }\end{array}$ & $\begin{array}{l}\text { At the end of } \\
\text { the research }\end{array}$ \\
\hline $\begin{array}{l}\text { I systematically complete tasks without delaying } \\
\text { the resolution of important issues }\end{array}$ & $\begin{array}{l}\text { - Yes }-35 \% \\
\text { - No }-65 \%\end{array}$ & $\begin{array}{l}\text { - Yes }-78 \% \\
\text { - No }-22 \%\end{array}$ \\
\hline $\begin{array}{l}\text { I characterize myself as a purposeful person and } \\
\text { always achieve my goal }\end{array}$ & $\begin{array}{l}\text { - Yes }-36 \% \\
\text { - No }-64 \%\end{array}$ & $\begin{array}{l}- \text { Yes }-68 \% \\
-\mathrm{No}-32 \%\end{array}$ \\
\hline I persevere to achieve my goals & $\begin{array}{l}\text { - Yes }-60 \% \\
\text { - No }-40 \%\end{array}$ & $\begin{array}{l}\text { - Yes }-65 \% \\
\text { - No }-35 \%\end{array}$ \\
\hline $\begin{array}{l}\text { I responsibly approach to the implementation of } \\
\text { tasks and submit them on time }\end{array}$ & $\begin{array}{l}\text { - Yes }-59 \% \\
- \text { No }-41 \%\end{array}$ & $\begin{array}{l}\text { - Yes }-64 \% \\
\text { - No }-36 \%\end{array}$ \\
\hline $\begin{array}{l}\text { While self-organization, I am using external } \\
\text { tools that allow me to better carry out independent } \\
\text { work }\end{array}$ & $\begin{array}{l}\text { - Yes }-74 \% \\
- \text { No }-26 \%\end{array}$ & $\begin{array}{l}\text { - Yes }-89 \% \\
\text { - No }-11 \%\end{array}$ \\
\hline
\end{tabular}

Based on the results of statistical data processing, we can talk about the following. At the beginning of the study, many students noted that their ability to self-organize requires improvement.

Table 2 shows the results of the analysis of indicators reflecting the formation of students' self-organization based on the survey data.

Table 2. The results of the analysis of indicators of students' self-organization at the beginning and at the end of the research

\begin{tabular}{|l|c|c|}
\hline \multirow{2}{*}{ Index } & \multicolumn{2}{c|}{ Average } \\
\cline { 2 - 3 } & At the beginning of the research & $\begin{array}{l}\text { At the end of the } \\
\text { research }\end{array}$ \\
\hline Regularity & 22.1 & 27.3 \\
\hline Determination & 23.5 & 25.5 \\
\hline Perseverance & 19,2 & 21,4 \\
\hline Resposibility & 23.3 & 24.2 \\
\hline $\begin{array}{l}\text { Self-organization using external } \\
\text { means }\end{array}$ & 18.9 & 20.3 \\
\hline
\end{tabular}

The presented statements allow us to form an idea of students' self-organization according to individual indicators ("regularity", "perseverance", "responsibility", "selforganization using external means"). 
REVISTA DE LA UNIVERSIDAD DEL ZULIA. $3^{\text {a }}$ época. Año 11 N 31, 2020 Inna K. Kirillova et al. /// The development of professional self-organization among students, 497-508

DOI: http://dx.doi.org/10.46925//rdluz.31.32

Purposefulness creates an image of a person who is ready to make every effort to achieve their goals. Students with a high level of determination prove their position reasonably, can cope with the difficulties that arise. However, high values of the "purposefulness" indicator are positive only if combined with high values of the "regularity" indicator. In this case, the student competently builds a strategy to achieve their goals. If "determination" is combined with low indicators of "orderliness" - the student, as a rule, seeks to achieve immediate goals, which indicates his inability to effectively interact with other participants in the process and take into account their arguments. At the beginning of the study, we observed that the rate of "regularity" among students was slightly lower than the rate of "determination". In the process, we were able to increase the level of these indicators. And at the end of the study (taking into account the high values of both indicators), "regularity" became higher than "determination". These indicators reflect the activity component of the formed competence. "Perseverance" shows the student's motivation for completing assignments. The indicator "responsibility" reflects the ability of students to complete on time and perform tasks in a quality manner. This indicator reflects the cognitive component of competency. And if for the allotted time for this work is not possible to complete, then bring objective arguments in their defense. The statistics allow us to say that many students are responsible in completing assignments. But by the end of the study, the percentage of students with a high level of responsibility becomes even higher.

The indicator "self-organization with the help of external means" reflects the willingness of students to seek additional tools to increase the effectiveness of activity planning and independent work. This indicator reflects the activity component of competence in self-organization. A higher than average level means that students are ready to use external means, including electronic ones, to perform work. Today, the use of additional funds is a prerequisite for the implementation of productive activities, especially independent. Electronic tools allow you to organize interaction in extracurricular conditions, make it possible to complete tasks at any convenient time. At the same time, the quality of training remains at a high level. Using external means, students show awareness of activity, the ability to conduct reflection, responsibility when doing independent work. 
REVISTA DE LA UNIVERSIDAD DEL ZULIA. $3^{a}$ época. Año $11 \mathrm{~N}^{\circ}$ 31, 2020 Inna K. Kirillova et al. /// The development of professional self-organization among students, 497-508

DOI: http://dx.doi.org/10.46925//rdluz.31.32

Conclusions

We considered the experience of developing professional self-organization among students. In the process of mastering the disciplines, students independently, with the support of the teacher, master new types of activities, the necessary materials, participate in group and individual work. The study on the formation of competence "the ability to manage your time, build and implement the path of self-development based on the principles of education throughout life" revealed the level of its formation and determine the opinion of students on their self-organization.

In determining the level of competence formation, a tendency is observed for the students to continuously move to a higher level of self-organization. Increasing the level of competence formation contributes to the preparation of a bachelor, capable of continuous professional growth in the conditions of continuing education.

The study allowed us to actualize the issue of the formation of self-organization among students. The importance of self-organization is confirmed by both checking the level of competence formation and students' self-esteem. The data obtained in the calculation of the main characteristics can be used in further, deeper analysis of the values.

Increasing the level of self-organization contributes to the purposeful construction of the learner's personality, increasing his responsibility, and the ability to work effectively at the level of world standards.

\section{References}

Aleksieienko-Lemovska, L.V. (2019). The activity approach as a basis for preschool teachers' methodological activities, Humanitarian Balkan Research, 3, 4(6), 10-14.

Andrienko, O.A. (2019a). On the need to apply gaming training technologies. Balkan Scientific Review, 2 (4), 5-8.

Andrienko, O.A. (2019b). Modern educational technologies: technology of self-presentation. Balkan Scientific Review, 1(3), 5-7.

Andriushchenko, T. K., (2018). Personal aspects of pedagogue's innovative culture, Scientific Vector of the Balkans, 1, 13-16.

Bakharev, N. P., (2019). Creativity - a prerequisite for the formation of professional competences in specialists of technical direction of training, Scientific Vector of the Balkans, 3, 4 (6), $17-21$. 
REVISTA DE LA UNIVERSIDAD DEL ZULIA. $3^{a}$ época. Año $11 \mathrm{~N}^{\circ}$ 31, 2020

Inna K. Kirillova et al. /// The development of professional self-organization among students, 497-508

DOI: http://dx.doi.org/10.46925//rdluz.31.32

Chertovskikh, O.O. (2019). Prospects for the use of digital resources in education. Baltiyskiy gumanitarnyy zhurnal (Baltic Humanitarian Journal). 8, 4 (29), 184-187. (in Russ.).

Cirdan, A.P. (2019). Innovative technologies of professional training of future economists in the system of continuous education. Humanitarian Balkan Research, 2(4), 27-30.

Donetskova, O.YU. (2019). Modernization of the modern education system in Russia. Baltiyskiy gumanitarnyy zhurnal (Baltic Humanitarian Journal), 8, 2 (27), 37-39. (in Russ.).

Filchenkova, I.F. (2019). Educational management of innovative activity of teachers as an object of pedagogical research. Vestnik Mininskogo universiteta (Vestnik of Minin University), 2019. 7 (4), 3. (in Russ.).

Gladkov, A.V., Vaganova, O.I., Prokhorova, M.P. (2019). Modern pedagogical technologies as a means of enhancing educational motivation. Baltiyskiy gumanitarnyy zhurnal (Baltic Humanitarian Journal). 8, 1 (26). 274-276. (in Russ.).

Grigoriev S. G., Shabunina V. A., Tsarapkina Ju. M., Dunaeva N. V. (2019). Electronic library system as a means of self-development of students of digital generation $Z$ (on the example of studying the course "Basics of the counselor activity") - Scientific and technical libraries. 2019. No. 7. Pp. 78-99. 29.

Halatsyn, K.A., Feshchuk, A.M. (2019). Diagnosing motivational-and-valuable component of the communicative culture of students in higher technical educational institutions, Balkan Scientific Review, 3, 2 (4), 17-20.

Klinkov, G.T. (2018). The specificity of manifestation of pedagogical communication as a special construct. Scientific Vector of the Balkans, 1, 51-52.

Komova, O. V. (2015). Theoretical bases of pedagogical maintenance of school students' selforganization, Nauchnyy zhurnal KubGAU, (Scientific journal KubGAU), 114 (10), (in Russ.)

Lutseva, I. Yu. (2014). Student self-organization of educational activities, Science time, 7, 229233 (in Russ).

Oros, I.I. (2018) The role of international connections in the development of the adult education system. Humanitarian Balkan Research, 1, 57-59.

Petrichev, P. V., Masyuk, N. N., Bushueva, M. A. (2018). Method of estimation of the effectiveness of the partnership russian universities with foreign educational organizations, Azimut nauchnykh issledovaniy (Azimuth of Scientific Researches: Economics and Management), 7, 3 (24), 229-232.

Pichugina G. A., Zhilyakova D. A. (2019). Structuring the organization of the process of creativity. Scientific Vector of the Balkans, 3, 3 (5), 55-58.

Pisarenko, D. A. (2019). Evaluation of extracurricular activities of university students with a competency-based approach, Scientific Vector of the Balkans, 3, 3 (5), 37-40. 
REVISTA DE LA UNIVERSIDAD DEL ZULIA. $3^{a}$ época. Año $11 \mathrm{~N}^{\circ}$ 31, 2020 Inna K. Kirillova et al. /// The development of professional self-organization among students, 497-508

DOI: http://dx.doi.org/10.46925//rdluz.31.32

Pliushch, V.M. (2018). Independent work of students as a factor of improving education quality. Balkan Scientific Review, 1, 69-71.

Ponachugin, A.V., Lapygin, Yu.N. (2019). Digital educational resources of the university: design, analysis and expertise. Vestnik Mininskogo universiteta (Vestnik of Minin University), 7 (2), 5. (in Russ.).

Raven, J. (2017). Education and Sociocybernetics, Azimut nauchnykh issledovaniy (Azimuth of Scientific Researches: Economics and Management), 6, 3 (20), 289-297.

Tolkanuk, Z. A. (2019). Professional self-determination of youth as a factor of training of a competent specialist, Balkan Scientific Review, 3, 2 (4), 57-59.

Tsarapkina, Ju. M., Dunaeva, N. V., Kireicheva, A. M. (2019). Application of BYOD technology in education on the example of Lecture Racing mobile application, Informatika i obrazovanie Informatics and Education, 9 (308), 56-64.

Vaganova, O.I., Ilyashenko, L.I., Smirnova, Zh.V., Bystrova, N.V., Kaznacheeva, S.N. (2019a). Students' creative abilities development in higher educational institution. Amazonia Investiga, $8(22), 701-710$

Vaganova, O.I., Rudenko, I.V., Markova, S.M., Smirnova, Zh.V., Kutepov, M.M. (2019b). The use of educational video materials in educational process of a higher educational institution. Amazonia Investiga, 8 (22), 216-222.

Vaskovskaya, G.A. (2018). Features of implementation of pedagogical technologies of profile training. Balkan Scientific Review, 1, 76-79. 